\title{
THE ROLE OF IMMUNOHISTOCHEMISTRY IN DIAGNOSIS OF LUNG CANCER WITH CORRELATION OF SERUM TUMOUR MARKER CARCINOEMBRYONIC ANTIGEN
}

\author{
Neha Pandya ${ }^{1}$, Vijay Popat ${ }^{2}$
}

13rd Year Resident, Department of Pathology, Shri M. P. Shah Government Medical College, Jamnagar, Gujarat, India. 2Professor and HOD, Department of Pathology, Shri M. P. Shah Government Medical College, Jamnagar, Gujarat, India.

\begin{abstract}
BACKGROUND
Immunohistochemistry is a less challenging, widely available technique which provides clinically meaningful results quickly and allows for cellular localization of proteins in the context of tumour structure. Lung cancer is the leading cause of cancer-related deaths worldwide, regardless of gender. In an era of precision medicine, pathologists are required to classify lung cancer into specific subtypes and assess biomarkers relevant to molecular targeted therapies but overlapping of microscopic features of different types of tumours sometimes makes diagnosis difficult for pathologists. The objectives of this study were- 1 . to accurately diagnose small and non-small cell lung carcinoma for targeted therapy. 2. to differentiate between adenocarcinoma lung and malignant mesothelioma. 3. to determine primary site of origin in patients who present with metastatic disease. 4 . to correlate serum CEA level and lung carcinoma.
\end{abstract}

ABSTRACT

\section{MATERIALS AND METHODS}

A descriptive study of 60 cases which have been diagnosed histopathologically and cases which were difficult to diagnose due to inadequate material, was carried out for six months duration from July 2018 to December 2018 in the Department of Pathology, Shri M. P. Shah Government Medical College, Jamnagar. We have studied histopathology slides with different IHC panel markers like TTF-1, Napsin A, CK 7, p63 and EGFR. Results were correlated with serum tumour marker Carcinoembryonic Antigen (CEA) with the help of Enzyme Linked Immunosorbent Assay (ELISA) technique.

\section{RESULTS}

In our study of 60 cases, 24 (40\%) cases of squamous cell carcinoma, 20 (33\%) cases of adenocarcinoma and 15 (25\%) cases of small cell lung carcinoma and $1(1.66 \%)$ case of metastasis from colon adenocarcinoma were confirmed. Most of the patients belonged to older age group and out of 60 cases, 39 (65\%) were males, and 21 (35\%) were females. Most common age group was 40-60 years.

\section{CONCLUSION}

Squamous cell carcinoma is more common than other subtypes of lung cancer with male predominance and was associated with smoking. Serum CEA level is raised ( $>7 \mathrm{ng} / \mathrm{ml}$ ) in all the cases of lung carcinoma. Immunohistochemical techniques along with serum tumour marker play critical roles as diagnostic and screening tools for lung cancer.

\section{KEY WORDS}

Immunohistochemistry, Serum Tumour Marker CEA, Small Cell Lung Carcinoma, Non-Small Cell Lung Carcinoma

HOW TO CITE THIS ARTICLE: Pandya N, Popat V. The role of immunohistochemistry in diagnosis of lung cancer with correlation of serum tumour marker carcinoembryonic antigen. J. Evolution Med. Dent. Sci. 2019;8(10):701-705, D0I: $10.14260 /$ jemds/2019/155

\section{BACKGROUND}

Immunohistochemistry is a widely available technique that is technically less challenging and can provide clinically meaningful results quickly and allows for cellular localization of proteins in the context of tumour structure with rapid turnaround time. Lung cancer being a leading cause of cancer related deaths worldwide, regardless of gender, in the era of precision medicine, pathologists are required to classify lung cancer into specific subtypes and assess biomarkers relevant to molecular targeted therapies. ${ }^{1}$

'Financial or Other Competing Interest': None.

Submission 10-01-2019, Peer Review 22-02-2019,

Acceptance 28-02-2019, Published 11-03-2019.

Corresponding Author:

Dr. Neha Pandya,

301, Dwarkesh Apartment,

Silver Park, Noble City,

Zanzarad Road, Jamnagar-362001,

Gujarat, India.

E-mail: drchapandya47@gmail.com

DOI: $10.14260 /$ jemds/2019/155
But overlapping of microscopic features of different types of tumours sometimes makes diagnosis difficult for pathologists. Squamous, adenocarcinoma and small cell carcinoma of lung are common malignancies affecting lung and for that basic IHC panel markers like P63, TTF-1, Napsin A, CK 7, CK 20 and EGFR should be performed. Serum tumour marker carcinoembryonic antigen (CEA) also plays an important role in diagnosis and prognosis of lung cancer. Normal value for serum CEA in smokers is $<7 \mathrm{ng} / \mathrm{ml}$ and in non- smoker $<5 \mathrm{ng} / \mathrm{ml}$.

\section{Objectives}

1. To accurately diagnose small and non-small cell lung carcinoma for targeted therapy.

2. To differentiate between adenocarcinoma lung and malignant mesothelioma.

3. To determine primary site of origin in patients who present with metastatic disease.

4. To correlate serum CEA level and lung carcinoma. 


\section{MATERIALS AND METHODS}

Type of Study

Descriptive study.

\section{Study Period}

Six months (from July 2018 to December 2018).

\section{Study Setting}

Department of Pathology, Shri M. P. Shah Government Medical College, Jamnagar.

\section{Sample Size}

60 cases.

\section{Sample Size}

Sample size was taken conveniently.

\section{Study Procedure}

Histopathology slides have been studied with different IHC panel markers like TTF-1, Napsin A, CK 7, P63 and EGFR.A general IHC protocol consists of four main steps: (1) fixation - to keep everything in its place, (2) antigen retrieval - to increase availability of proteins for detection, (3) blocking and (4) antibody labelling and visualization. Cases have been correlated with serum tumour marker CEA (Carcinoembryonic antigen) also. All of IHC stains were performed at our clinical immunohistochemistry laboratory as previously described. Briefly, the specimen were sectioned at 5 micron size, deparaffinised and incubated with primary and secondary antibodies. Staining characteristics were reviewed and considered along with intensity and distribution of staining patterns. A case was considered to be positive if greater than $5 \%$ of tumour cells with an appropriate staining patterns were identified; otherwise case was considered to be negative. In terms of staining pattern, coarse granular cytoplasmic staining was considered positive for Napsin A, nuclear staining for TTF-1, cytoplasmic staining for CK 7, diffuse nuclear staining for P63 and membranous staining for EGFR. Care was taken not to interpret entrapped normal bronchial epithelium or pulmonary macrophages as a positive staining. For serum CEA, sandwich ELISA technique was used with help of Calbiotech company kit insert having standard range from $5-250 \mathrm{ng} / \mathrm{ml}$.

\section{Inclusion Criteria}

Patients who attended TB- Chest Department, Guru Gobind Singh Government General Hospital, and Jamnagar with radiologically diagnosed lung mass. Also, cytopathologically and histopathologically diagnosed or suspicious of malignancy of lung carcinoma or any metastatic carcinoma and with raised value of serum CEA.

\section{Exclusion Criteria}

Benign, inflammatory, infective aetiology of lung pathology by radiology, cytopathology or histopathology and with inadequate material for immunohistochemistry and inadequate data.

\section{Data Management and Analysis}

The data was entered in Microsoft Excel and further statistical analysis was done using SPSS software (Version
17). The statistical methods used were mean, frequency, proportion and non-parametric test (chi-square test). The level of significance was indicated as ' $p$ ' value $<0.0001$.

\section{RESULTS}

Most of the patients belonged to older age group and most common age group was 40 to 60 years. In our study of 60 cases, $24(40 \%)$ cases of squamous cell carcinoma being the most common with P63 positivity, 20 (33\%) cases of adenocarcinoma with TTF-1, CK 7, EGFR and Napsin A positivity with negative P63 and 15 (25\%) cases of small cell lung carcinoma with TTF-1 positivity and Napsin A negativity and $1(1.66 \%)$ case of metastasis from colon adenocarcinoma with CK7 negativity and CK20 positivity were confirmed and out of 60 cases, 39 (65\%) were males and 21 (35\%) were females. So, male to female ratio was 1.8:1. Serum tumour marker CEA level was raised ( $>7 \mathrm{ng} / \mathrm{ml}$ ) in all the cases. The smallest tumour diameter was $1 \mathrm{~cm}$ and the largest $10 \mathrm{~cm}$, with a mean diameter of $4.01 \pm 2.09 \mathrm{~cm}$. We found a statistically significant difference in favour of adenocarcinoma versus SqCC $(\mathrm{P}<0.0001)$ in the analysis of Napsin-A staining and in favour of SqCC versus adenocarcinoma $(\mathrm{P}<0.0001)$ in the analysis of $\mathrm{P} 63$ staining tumour type. There was no statistically significant correlation between the distribution of cases by stages or tumour types $(\mathrm{P}>0.05)$.

\begin{tabular}{|c|c|}
\hline Histology & Positive Markers \\
\hline Squamous Cell Carcinoma & $\begin{array}{l}\text { CK5/6, P63, Vimentin, CEA, } \\
\text { S-100, EMA }\end{array}$ \\
\hline Adenocarcinoma & $\begin{array}{l}\text { TTF-1, Napsin A, CK7, } \\
\text { Keratin 7, MUC Family }\end{array}$ \\
\hline Small Cell Carcinoma & \begin{tabular}{|c|} 
TTF-1,CD56, Synaptophysin, \\
Chromogranin
\end{tabular} \\
\hline Large Cell Carcinoma & $\begin{array}{l}\text { Cytokeratin, TTF-1, CD56, } \\
\text { NSE (Rare) } \\
\end{array}$ \\
\hline Neuroendocrine Tumours & $\begin{array}{l}\text { TTF-1,CD56, Synaptophysin, } \\
\text { Chromogranin }\end{array}$ \\
\hline Adenosquamous Carcinoma & $\begin{array}{c}\text { Both Markers of Adeno and } \\
\text { Squamous }\end{array}$ \\
\hline $\begin{array}{r}\text { Sarcomatoid Car } \\
\text { Carcinosarc } \\
\end{array}$ & $\begin{array}{c}\text { Cytokeratin, Vimentin, CEA, } \\
\text { EMA }\end{array}$ \\
\hline Pulmonary bla & $\begin{array}{c}\text { CD117, Surfactant Protein B, } \\
\text { Vimentin, Desmin }\end{array}$ \\
\hline $\begin{array}{r}\text { Metastatic Maligr } \\
\text { Colon And Ot }\end{array}$ & CDX2, CK7-/CK20+ \\
\hline $\begin{array}{l}\text { Metastatic Malignancy from } \\
\text { Prostate } \\
\end{array}$ & PSA \\
\hline $\begin{array}{c}\text { Metastatic Malignancy from } \\
\text { Breast }\end{array}$ & ER, PR, Her2/Neu \\
\hline $\begin{array}{c}\text { Metastatic Malignancy from } \\
\text { RCC, Mullerian, Thyroid, } \\
\text { Thymus }\end{array}$ & PAX8 \\
\hline $\begin{array}{c}\text { Metastatic Malignancy from } \\
\text { Germ Cell }\end{array}$ & SALLA4 \\
\hline $\begin{array}{c}\text { Metastatic Malignancy from } \\
\text { Urothelial, Squamous, Thymus }\end{array}$ & P63 \\
\hline $\begin{array}{l}\text { Metastatic Malignancy from } \\
\text { Mesothelioma, Mullerian }\end{array}$ & WT1 \\
\hline $\begin{array}{l}\text { Metastatic Malignancy from } \\
\text { Hepatocellular Carcinoma }\end{array}$ & HepPar1 Ab \\
\hline \multicolumn{2}{|c|}{$\begin{array}{l}\text { Table I. Common IHC Markers Used in Diagnosis of Lung } \\
\text { Cancer }\end{array}$} \\
\hline
\end{tabular}


We performed following basic IHC panel to differentiate between adenocarcinoma and squamous cell carcinoma of lung.

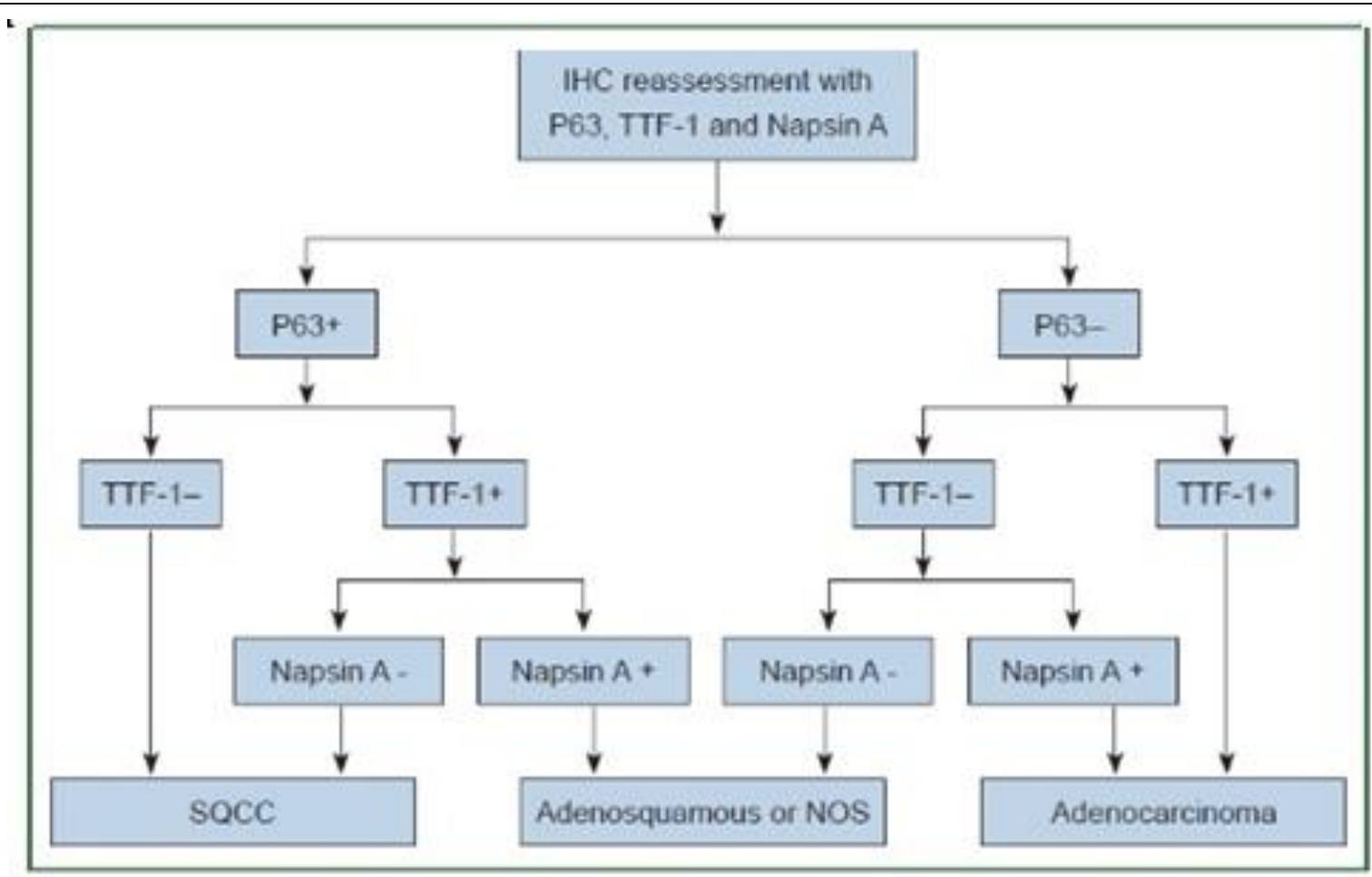

\begin{tabular}{|c|c|c|c|}
\hline Positive IHC Marker & Peh Sun Loo et al ${ }^{2}$ & Argon $A$ et al $^{3}$ & Present Study \\
\hline p63 (SqCC) & 25 & 72 & 24 \\
\hline Napsin A, TTF-1, EGFR, (Adeno) & 16 & 19 & 20 \\
\hline TTF-1, Synaptophysin, Chromogranin (Small cell) & 00 & 00 & 15 (TTF 1+ve) \\
\hline CK7-ve/CK20+ve (Colon Mets) & 00 & 00 & 01 \\
\hline \multicolumn{4}{|c|}{ Table II. Comparison of IHC Markers with Other Studies } \\
\hline
\end{tabular}

\begin{tabular}{|c|c|c|c|c|}
\hline IHC Marker & SqCC & Adeno-Carcinoma & Small cell Carcinoma & Metastatic Carcinoma \\
\hline p63 & 24 & 00 & 00 & 00 \\
\hline Napsin A & 00 & 20 & 00 & 00 \\
\hline TTF-1 & 00 & 20 & 15 & 00 \\
\hline CK7-ve/ CK20+ve & 00 & 00 & 00 & 01 \\
\hline \multicolumn{5}{|l}{ Table III. Correlation of Types of Carcinoma with IHC Marker } \\
\hline Above table gives Chi square value 177 with DF of 9 and p value <0.0001. \\
\hline
\end{tabular}

\begin{tabular}{|c|c|c|c|c|c|c|}
\hline \multirow[t]{2}{*}{ Study } & \multirow[t]{2}{*}{ H \& E Diagnosis } & \multirow[t]{2}{*}{ Total No. of Cases } & \multicolumn{4}{|c|}{ IHC Diagnosis } \\
\hline & & & SqCC & Adeno Ca & Small Cell Ca & Mets \\
\hline \multirow{2}{*}{$\begin{array}{c}\text { Peh Sun Loo } \\
\text { et } \mathrm{al}^{2}\end{array}$} & SqCC & 25 & 25 & - & - & - \\
\hline & Adeno Ca & 16 & - & 16 & - & - \\
\hline \multirow{2}{*}{$\begin{array}{c}\text { Argon A } \\
\text { et } \mathrm{al}^{3}\end{array}$} & SqCC & 72 & 72 & - & - & - \\
\hline & Adeno Ca & 19 & - & 15 & - & - \\
\hline \multirow{4}{*}{$\begin{array}{l}\text { Present } \\
\text { Study }\end{array}$} & SqCC & 24 & 24 & - & - & - \\
\hline & Adeno Ca & 20 & - & 20 & - & - \\
\hline & Small Cell Ca & 15 & - & - & 15 & - \\
\hline & Mets from Colon & 01 & - & - & - & 1 \\
\hline \multicolumn{7}{|c|}{ Table IV. Correlation of Histopathological Diagnosis and IHC Diagnosis } \\
\hline
\end{tabular}




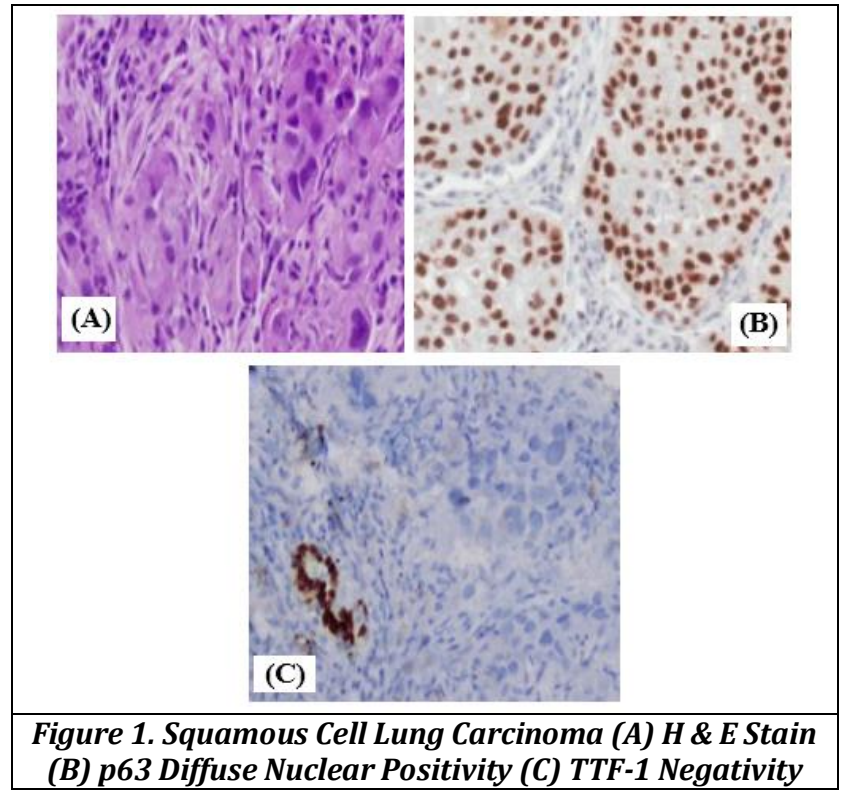

This tumour was also negative for EGFR.

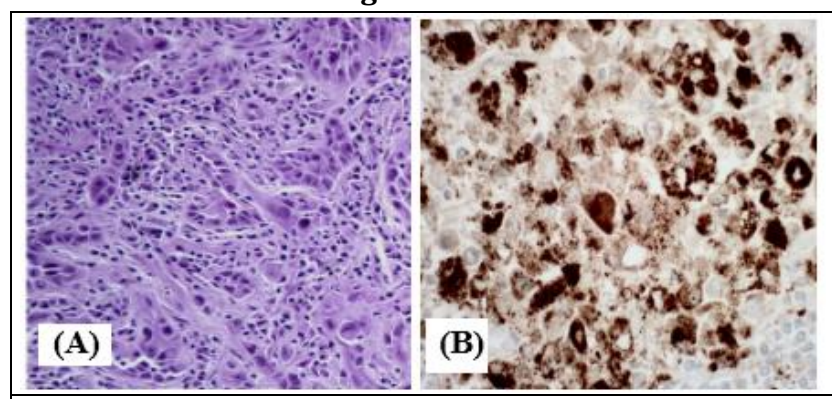

Figure 2: Adenocarcinoma of Lung. (A) H \& E Stain (B) Napsin A Coarse Granular Cytoplasmic Positivity

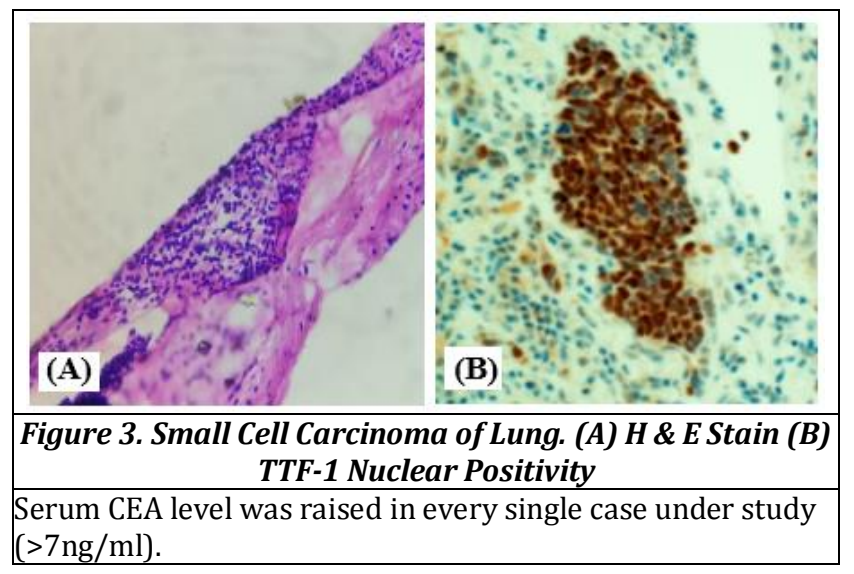

\section{DISCUSSION}

Primary lung carcinoma is the most common carcinoma in the world today. Immunohistochemistry gives confirmatory diagnosis for various subtypes of lung carcinomas which is necessary for targeted therapies. The present study was conducted on 60 cases of radiologically diagnosed lung cancer at Department of Pathology, Shri M. P. Shah Government Medical College, Jamnagar from July 2018 to December 2018.

$64 \%$ of patients presented with cough, 62\% with dyspnoea, $36 \%$ with haemoptysis, $26 \%$ with pleuritic chest pain and $1 \%$ case had features of metastasis as initial presentation. Mean age group in present study was 40 to 60 years.

TTF-1 (Thyroid transcription factor-1) is a nuclear transcription factor necessary for development of thyroid and pulmonary tissue. This DNA binding protein was first identified in thymocytes (Hence its name) and later in pneumocytes. ${ }^{4}$ It is expressed in most cases of lung carcinoma (Especially adenocarcinoma) including small cell neuroendocrine type and has become one of the most useful markers in differential diagnosis between lung carcinoma and carcinomas of other sites in one side and mesotheliomas on the other, both in histologic sections and cytologic preparations. ${ }^{5}$ As usual, there is a catch: high grade neuroendocrine carcinomas of nonpulmonary origin (but not Merkel cell carcinomas), nephroblastoma, ovarian carcinomas and endometrial cancers can also stain in occasional cases. $6,7,8$

P63 (A member of the P53 family involved in the development of epithelial tissues) is expressed in nearly all pulmonary squamous cell carcinomas but also in a significant subset of the other types, including the majority of small cell carcinomas. ${ }^{9}$

Napsin A (TA02) is a marker resulting in granular cytoplasmic staining. It is an aspartic proteinase (Homologous with polypeptide TA02 that was detected by gel electrophoresis of lung adenocarcinomas) involved in the maturation of surfactant protein B and expressed in type II pneumocytes, in alveolar macrophages and in epithelium of proximal and convoluted tubules of kidney. Napsin A has slightly higher sensitivity for pulmonary adenocarcinomas when compared with TTF-1. Like for the latter, Napsin A positivity decreases with increasing tumour grade. ${ }^{10}$

Although both CK7 and CK20 are intermediate filaments, they are located in different epithelial cells. CK7, a 54-kDa basic protein, is typically located in epithelia from lung and breast; CK20, a 46-kDa acidic cytokeratin protein, is common in epithelia from the intestinal tract.11 CK7 is known to label several types of normal and neoplastic glandular epithelia; carcinomas from the GI tract and prostate generally are negative, whereas breast, lung, and subtypes of adenocarcinomas of the ovary generally are positive. ${ }^{12}$ Since the early 1990s, the clinical utility of monoclonal antibodies directed against CK20 paired with anti-CK7 antibodies in the differential diagnosis of primary lung cancers and secondary lung cancers has been reported.13 Adenocarcinoma from the colon is usually CK20+ and CK7-, whereas adenocarcinoma from the lung is usually CK20- and CK7+. ${ }^{14}$ In current study we found a case of adenocarcinoma metastasis from colon to lung with CK7- and CK20+.

EGFR (Epidermal growth factor receptor) belongs to the erbB family of closely related receptor tyrosine kinases, which include erbB1 (Also known as EGFR), erbB2 (HER2), erbB3, and erbB4. Although their basic structures are similar, each one has distinct properties, including variation in tyrosine kinase activity. It has an extracellular ligand binding domain, a transmembrane portion, and intracellular tyrosine kinase and regulatory domains. Upon binding of a specific ligand (e.g. epidermal growth factor), the normally functioning EGFR undergoes conformational change and phosphorylation of the intracellular domain occurs, leading to downstream signal transduction by various pathways. These include the Raf1-extracellular signal-regulated kinase, 
PI3K/Akt, and signal transducer and activator of transcription (STAT) factors. Depending on the pathway, the end result is cell proliferation or cell maintenance by inhibition of apoptosis. ${ }^{15}$ It is having a prognostic role in targeted therapies mainly for adenocarcinoma of lung. Though utility of EGFR overexpression detection by IHC is controversial in various studies, it is helpful in prediction of response to tyrosine kinase inhibitor therapies.

Serum tumour marker CEA (Carcinoembryonic antigen) is a glycoprotein of heterogeneous composition (MW 200000) normally detected in glycocalyx of fetal epithelial cells, mainly those of mucin secreting glandular nature. ${ }^{16}$ It is detectable only in small amounts in normal adult cells and benign tumours bt is present in large quantities in carcinomas, particularly adenocarcinomas of lung and gastrointestinal tract along with medullary thyroid carcinoma. Because of the fact that it is primarily expressed by fetal tissues and malignant tumours, it is referred to as an oncofetal antigen. Monoclonal antibodies offer a greater degree of tumour specificity of tumour than conventional antisera. ${ }^{17}$

\section{CONCLUSION}

Squamous cell carcinoma is more common than other subtypes of lung cancer with male predominance and positive p63 and is strongly associated with smoking. Due to paucity of material in lung biopsy, immunohistochemical techniques play critical role as diagnostic and screening tool for lung cancer in current era of medicine along with CEA serum tumour marker. Histopathology, serum tumour marker and immunohistochemistry correlation will lead to perfect diagnosis for any lung cancer, serving as diagnostic and prognostic tools for better outcome of patients. In current WHO classification, immunohistochemical analysis is indispensable to the determination of lung cancer subtypes.

\section{ACKNOWLEDGEMENT}

I express my heartfelt thanks and gratitude to Dr. Vijay C. Popat, Head of the Department, Department of Pathology, Shri M. P. Shah Government Medical College, Jamnagar for his support and guidance.

\section{REFERENCES}

[1] Cagle PT, Allen TC, Bernicker EH, et al. Impact of recent developments in Lung Cancer on the practice of pathology. Arch Pathol Lab Med 2016;140(4):322-5.

[2] Loo PS, Thomas SC, Nicolson MC, et al. Subtyping of undifferentiated non-small-cell carcinomas in bronchial biopsy specimens. Journal of Thoracic Oncology 2010;5(4):442-7.

[3] Argon A, Nart D, Veral A. The value of cytokeratin 5/6, p63 and TTF-1 in adenocarcinoma, squamous cell carcinoma and non-small-cell lung cancer of the lung. Turk Patoloji Derg 2015;31(2):81-8.

[4] Lau SK, Luthringer DJ, Eisen RN. Thyroid transcription factor-1: a review. Appl Immunohistochem Mol Morphol 2002;10(2):97-102.
[5] Ng WK, Chow JC, Ng PK. Thyroid transcription factor-1 is highly sensitive and specific in differentiating metastatic pulmonary from extrapulmonary adenocarcinoma in effusion fluid cytology specimens. A study of 36 cases. Cancer 2002;96(1):43-8.

[6] Agoff SN, Lamps LW, Philip AT, et al. Thyroid transcription factor-1 is expressed in extrapulmonary small cell carcinomas but not in other non-pulmonary neuroendocrine tumours. Mod Pathol 2000;13(3):238-42.

[7] Bisceglia M, Ragazzi M, Galliani CA, et al. TTF-1 expression in nephroblastoma. Am J Surg Pathol 2009;33(3):454-61.

[8] Zhang MF, Zhang ZY, Fu J, et al. Correlation between expression of p53, p21/WAF1 and MDM2 proteins and their prognostic significance in primary hepatocellular carcinoma. J Transl Med 2009;7:110.

[9] $\mathrm{Au}$ NH, Gown AM, Cheang M, et al. P63 expression in lung carcinoma; a tissue microarray study of 408 cases. Appl Immunohistochem Mol Morphol 2004;12(3):240-7.

[10] Bishop JA, Sharma R, Illei PB. Napsin A and thyroid transcription factor-1 expression in carcinomas of the lung, breast, pancreas, colon, kidney, thyroid and malignant mesothelioma. Hum Pathol 2010;41(1):205.

[11] Cai YC, Banner B, Glickman J, et al. Cytokeratin 7 and 20 and thyroid transcription factor 1 can help distinguish pulmonary from gastrointestinal carcinoid and pancreatic endocrine tumours. Hum Pathol 2001;32(10):1087-93.

[12] Loy TS, Calaluce RD, Keeney GL. Cytokeratin immunostaining in differentiating primary ovarian carcinoma from metastatic colonic adenocarcinoma. Mod Pathol 1996;9(11):1040-4.

[13] Wauters CC, Smedts F, Gerrits LG, et al. Keratins 7 and 20 as diagnostic markers of carcinomas metastatic to the ovary. Hum Pathol 1995;26(8):852-5.

[14] Chhieng DC, Cangiarella JF, Zakowski MF, et al. Use of thyroid transcription factor $1, \mathrm{PE}-10$, and cytokeratins 7 and 20 in discriminating between primary lung carcinomas and metastatic lesions in fine-needle aspiration biopsy specimens. Cancer 2001;93(5):3306.

[15] Inamura $K$, Ninomiya $H$, Ishikawa $Y$, et al. Is the epidermal growth factor receptor status in lung cancers reflected in clinicopathologic features? Arch Pathol Lab Med 2010;134(1):66-72.

[16] Gold P, Shuster J, Freedman SO. Carcinoembryonic antigen (CEA) in clinical medicine: historical perspectives, pitfalls and projections. Cancer 1978;42(Suppl 3):1399-405.

[17] Jothy S, Brazinsky SA, Chin-A-Loy M, et al. Characterization of monoclonal antibodies to carcinoembryonic antigen with increased tumour specificity. Lab Invest 1986;54(1):108-17. 